\title{
Impact of Cultural Clash on Isabel's Marriage
}

\author{
Cui Chunyan \\ Foreign Languages Department \\ Qingdao Agricultural University \\ Qingdao, China
}

\begin{abstract}
This paper tries to analyze the impact of cultural clash on Isabel's marriage from the two aspects: choice of marriage and marriage life. The clash of American culture and European culture pushed Isabel to make a wrong choice in her marriage and thus begun a tragic marriage life with Osmond. More and more transnational marriages and cross-region marriages appeared in today's increasingly fierce trend of globalization. Isabel's tragic marriage has a warning significance for those who are deeply troubled by marriage.
\end{abstract} life

Keywords-Cultural clash; Isabel; Marriage choice; Marriage

\section{INTRODUCTION}

Henry James is a remarkable writer in the world literature. Born in a wealthy family in America, he was sent to Europe to get education since he was very young. Henry James traveled among different countries in Europe and experienced the cultural clash by himself. In Europe, he noticed a group of people who had the same experience with him. He put these people with their experience into his novels and gained great success. The Portrait of a Lady is one of the most outstanding novels of Henry James. It tells about an American girlIsabel's European experience. In Europe, this American girl suffered from the conflicts between two cultures-newly developed American culture and the ancient European culture, which deeply influenced her marriage. After this book was published, it has been studied by scholars from various aspects such as writing style, character and psychological analysis, feminism, stream of consciousness, international theme, and marriage, among which the international theme is the most popular, because it is the permanent theme of Henry James' works. The international theme means the clash of American inexperience and European complication. Henry James is very good at the expression of this theme. "The Europeans in James' novel are more cultured, more concerned with art, and more aware of the subtleties of social situations than are James' Americans. The Americans, however, usually have a morality and innocence which the European Lack. [1]" Through his works, Henry James attempted to find out the cultural identity contributing to the conflicts.

\section{IMPACT OF CULTURAL Clash ON ISABEL'S CHOICE OF MARRIAGE}

"It seems that Henry James aimed at portraying a 'new woman': Isabel Archer who is frequently labeled as an independent lady" [2]. Isabel was a clever, energetic, and imaginative American girl. Like other Americans, she adored freedom and independence. Her love for reading books helped her become knowledgeable and imaginative and develop a good taste for art. What's more, Isabel appreciated European civility very much. However, after she arrived in Europe, the European traditions and customs conflicted with her pursuit for independence and freedom. After staying in Europe for some years, the American girl also developed some European characteristics. The two kinds of cultures interacted with each other and influenced Isabel's marriage.

As to Isabel's love story, three totally different men played important roles, who stand for three different kinds of cultures. They are: Lord Warburton, a cultivated English nobleman, who stand for the traditional English culture; Caspar Goodwood, a successful American enterpriser, who stand for the new American culture; and Mr. Osmond, a Europeanized expatriate, who stand for the interweaving and collision of the two cultures. Isabel refused the first two suitors, and accepted the third one who brought her into a disastrous marriage. The reason why Isabel made such a choice seems to be related to her life experience. In fact, it is the social and cultural influence that accounted for her choice. Her tragic marriage could not be separated from the cultural clash between the English and American cultures. In this sense, her tragedy was doomed.

\section{A. Isabel's Refusal to Lord Warburton}

As a cultivated nobleman, Lord Warburton was a fine representative of the outstanding European culture. With cultivated manners, nice appearance, good personality, and great wisdom, he seemed to combine all superior conditions together without any shortage. His noble identity and excellent personality made him the Prince Charming that every traditional European girl dreamed for. At the first sight of Isabel, he was attracted by the optimistic young girl. Not long after he knew Isabel, Lord Warburton proposed to Isabel regardless of the predictable puzzle from people around him, only to be refused. Isabel admitted that Lord Warburton was very charismatic, and she especially appreciated his gentle manners. It seemed that she could not find out any shortcomings of the young man. She could not find any better 
excuse for her decision, and the only ridiculously reason is that she could not escape her fate. The so-called "fate", in fact, is the environment in which she grows up, that is, the influence of American culture on her. America is "the land of free", and the American culture is actually a culture of freedom. As an American girl, Isabel was used to the free climate of her society. She wanted to fully experience the happiness and pain of life by herself freely, without being influenced and constrained by the outside world. Isabel liked the civility of the ancient Europe, but she did not want to be bound by this civilization. The social system of England also made Isabel feel suffocated. When Warburton proposed, she felt that "a territorial, a political, a social magnate had conceived the design of drawing her into the system in which he rather individually lived and moved. [3]" The innocent Isabel thought that Warburton was so powerful that if she married him, he could provide her an easy life, and thus deprive her of the freedom to experience the world by herself. As an American girl, the freedom to experience the world at her will was much more attractive than an easy life. The desire for adventure and freedom of typical Americans pushed Isabel to refuse Lord Warburton. Warburton's proposal happened not long after Isabel's arrival in England, and in the clash of the two cultures, Isabel chose to defend her freedom.

\section{B. Isabel's Refusal to Caspar Goodwood}

Caspar Goodwood was a promising American young man. Henrietta, Isabel's best friend, insisted that Isabel should marry Caspar Goodwood. This is a perfect match in her eye. She always provided Goodwood with information about Isabel and tried her best to make them into a couple. But she did not succeed. Caspar Goodwood was a typical American: firm, frank, active, honest, and aggressive. His being refused can be traced back to Isabel's love for European culture.

Caspar Goodwood was a very capable young man. In America, He inherited his father's cotton mill and managed it in good order. He was called "Star of America". Although Isabel admired this young man for his ability and talent, she could not bear his vulgarity, which characterized the American culture at that time. It is just the American style of vulgarity in Caspar Goodwood's character that pushed Isabel further and further away from him. Isabel was learned in books and the gentility in European civility left her deep impression. Isabel loved the European style of courtesy which Goodwood happened to be lack of. Goodwood had the kind of American arrogance, and he cared nothing for England. The culture and art of Europe is not worth mentioning in his eye. His contempt for the civilization of Europe made Isabel feel that he had no art appreciation and was lack of taste, because Isabel thought highly of the European civility. Different cultures cultivated different tastes. Goodwood despised the European culture, while Isabel was an ardent admirer of the European culture. Isabel was deeply attracted by the European civilization, thus the vulgarity and rudeness of Goodwood only made him rejected.

\section{Isabel's Acception of Osmond}

Osmond was accepted by Isabel for the following two reasons. On the one hand, He catered to Isabel's pursuit of freedom. Being brought up in Europe, Osmond was totally Europeanized, but he pretended to be an "original without being an eccentric" [4]. He made Isabel feel that he possessed the American character of pursuing freedom. When Isabel showed her desire for experiencing the world, Osmond gave her encouragement. Isabel felt that he cared no worldly possessions and desired for the same free way of life as Isabel did. So Isabel was deeply attracted by this young man. Compared with the other two suitors, Osmond was nothing at all in most people's eyes. He had no money, no fame, neither good reputation, and he was only a small potato. However, it was just his processing nothing that appealed Isabel most. Isabel thought that lacking of these things would make Osmond avoid many constraints. He assured her that "he had no superstitions, no dull limitations, and no prejudices that had lost their freshness" [5]. He made Isabel feel that he was a man living in the fresh open air. Inherited a large amount of money from her uncle, Isabel thought that she would be able to support her own life, so that she would enjoy more freedom. There would not be too much limitation in her life; she could explore the world at her will.

On the other hand, Osmond took advantage of the girl's admiration for European culture. He once lived in Italy for many years, so the exquisite Rome civilization endowed Osmond with an elegant appearance. He collected many artworks and he had a gift for art, which just met Isabel's admiration for art. He made Isabel feel that "he lived by himself, in a sorted gifted arranged world, thinking about art, beauty and history" [6].

The American culture made Isabel adore freedom, while the fine European culture also appealed her deeply. In Isabel's view, Osmond was the perfect combination of the two cultures. Although everyone around her warned her, she still could not see though Osmond. Osmond pretended that he cared nothing and could give Isabel enough freedom. Osmond's tastes for art met Isabel's curiosity for ancient European civility. So Osmond captured Isabel's heart by successfully taking advantage of his identity as an American expatriates.

Isabel's independence determines that she won't choose the two seemingly mighty suitors. Just like other typical Americans, she loves her freedom immensely, so she will not depend on others. She would rather give than accept others' favor. Lord Warburton and Goodwood are too mighty and their social status gives Isabel too much pressure. Osmond has nothing, so Isabel thinks there will be no pressure to marry Osmond. What's more, it seems that Osmond possesses both the American spirit of freedom and the courtesy of the Europeans. To the American girl who has a strong American character and ardent love for the European civilization, Osmond is the only perfect choice. 


\section{IMPACT OF CULTURAL CLASH ON ISABEL'S MARRIAGE LIFE}

The marriage chosen under the influence of cultural clash must not be a harmonious marriage. After the brief happiness of their marriage, the differences between the two people quickly broke out. Both Isabel and Osmond felt they were put upon. Their indifference towards each other made their life suffocating. Cultural clash may account for that to some extent Isabel didn't read Osmond right, neither Osmond read Isabel right. They hold totally different views on many things. Osmond insisted his traditional European values, while Isabel could not get rid of her American ways of thinking. In this case, their marriage is hard to be happy, and life is full of contradictions.

One embodiment of their contradictions lies in their different senses of hierarchy. Their different attitudes to Lord Warburton in the novel can be a good illustration. Influenced by European traditional values, Osmond had a profound concept of hierarchy and valued social status. In the novel, his attitude towards Lord Warburton was totally different from his attitude towards Isabel's other friends. When he heard that Lord Warburton was interested in his daughter Pansy, he was overjoyed, and asked Isabel to persuade Passy to marry him, regardless of Pansy's true feeling. Like many other Europeans, Osmond wanted to marry his daughter to a wealthy and respectable man with high social status. In his opinion, reputation and money was much more important than real love. Osmond disliked Isabel's other friends, because they didn't belong to the respectable European upper class.

Isabel believed the basic American assumption that all men are created equal; she didn't have so deep values of class as Osmond. Once in her conversation with her uncle $\mathrm{Mr}$. Douchet, she showed her dissatisfaction towards class. Her uncle comforted her that she did not belong to any class. She replied that "I hope so, imagine one's belonging to an English class" [7]. Unlike Osmond, she preferred Warburton's elegant demeanor rather than his high social status.

The other embodiment of their contradictions lies in their different concepts of education. Osmond valued the European way of Education. According to the European traditions, education for girls stressed on socializing skills. It required girls to be pure before marriage and to be good housewives after marriage, devoting all themselves to their family. So Osmond sent Pansy to convent to be educated. Osmond required Pansy to behave according to the requirement of European traditions so that she could be married to the upper class. He raised Pansy in the way of regulated convent life, so Pansy was obedient, and she dared not to rebel Osmond's order.
Isabel had different views about education from Osmond, which can be traced back to the different cultures they lived in Isabel's father encouraged his girls to see more of this world. When Isabel was a little girl, her father brought the sisters to travel around the world. Those American ways of education shaped Isabel's characters of longing for freedom. In this case, Isabel highly valued the right to choose freely. She thought Pansy had the right to choose her own life, and Osmond should respect Pansy's idea instead of imposing his own wishes on her.

\section{CONCLUSION}

It can be said that cultural clash has caused Isabel's tragic marriage to a certain extent. In today's ever-changing society, this theme still has the value of research and it especially has a certain educational significance for today's young people in their choice of marriage. Internationally, more and more transnational marriages have emerged under the impact of internationalization. From the domestic point of view, marriages across provinces and areas are no longer new. Cultural differences among countries are obvious, and there are also different levels of cultural differences among regions in a country. However, "We are not always aware of the influence of our culture, when cultural clash do arise, they may be perceived as personal rather than cultural" [8]. The impact of cultural clash may account for the social phenomenon of rising divorce rates. If different cultures can get more respect, understanding and tolerance, marriage will be happier, and the society will be more harmonious.

\section{REFERENCES}

[1] Lu Min and Chen Yijun, A study of famous American literary works: English [M], Shanghai: Shanghai Jiao Tong University press, 2011, pp.136.

[2] Li Liangyan, Paradoxes in Isabel Archer's View of Freedom in The Portrait of a Lady, http://dlib.edu.cnki.net/kns50/detail.aspx?dbname=CJFD2011\&filename =HWYY201108155 (accessed 13.05.2012).

[3] James, Henry, The Portrait of a Lady [M], London: Oxford University Press, 1981, pp. 108.

[4] James, Henry, The Portrait of a Lady [M], London: Oxford University Press, 1981, pp. 282.

[5] James, Henry, The Portrait of a Lady [M], London: Oxford University Press, 1981, pp. 466.

[6] James, Henry, The Portrait of a Lady [M], London: Oxford University Press, 1981, pp. 282.

[7] James, Henry, The Portrait of a Lady [M], London: Oxford University Press, 1981, pp. 59.

[8] Zhao Yanping and Li Lianjie, Culture and Communication [M], Beijing: Renmin University of China press, 1999, pp.42. 